\section{Amgen to spend $\mathbf{\$ 8 0}$ million to create Canadian institute}

\begin{abstract}
Washington. A Canadian subsidiary of Amgen Inc. of Thousand Oaks, California, will spend C\$100 million (US\$80 million) over the next ten years to create a medical research institute in Toronto that will study the human immune system and
\end{abstract} how it relates to diseases such as cancer. The institute is another indication that the US biotechnology industry has matured to the point where its leading companies can begin to emulate the global pharmaceutical giants by looking outside their own laboratories for the next blockbuster drug. However, that strategy is not without its own risks (see below).

The Amgen Institute will be located next to and will retain strong links with the Ontario Cancer Institute/Princess Margaret Hospital (OCL/PMH). It will be headed by Tak Wah Mak, an immunologist who in 1984 discovered the T-cell receptor. Mak resigned as head of the division of cellular and molecular biology at OCI/PMH to take up the new post but will still be a member of that department. The affiliation agreement will allow $\mathrm{OCI} / \mathrm{PMH}$, Canada's largest cancer treatment and research centre which is affiliated with the University of Toronto, to create a fully endowed research chair and strengthen its training programme as well as to recruit top scientists to the area. The grant-funded research arm of OCI/PMH has an annual budget of about C\$15 million.

In return for its investment, Amgen has acquired the exclusive rights to all pending patents currently held by the cancer centre in the area of gene knockout mice (based on Mak's work for the past four years) and all rights to any inventions derived from the new institute. Those rights extend only to the work of Mak and employees of the new institute and not to the 36 senior scientists who will continue to work for the cancer centre. As part of the affiliation agreement, the cancer centre will retain some influence over the governance, recruitment and review procedures of the new institute.

Founded in 1980 and with two of the topselling biopharmaceuticals on the market (in Epogen and Neupogen), Amgen is in the enviable position of being one of a few biotechnology companies generating product sales, with revenues last year of US\$1.128 billion. Setting up a complementary research arm with close ties to an academic institution will provide Amgen with "a direct pipeline into the newest technologies, techniques and information", says Mak.

Preliminary negotiations were focused on a collaboration with the cancer centre. Eventually, however, Amgen decided to create an institute affiliated closely with $\mathrm{OCI} / \mathrm{PMH}$ and led by Mak that would carry

\section{IMAGE
UNAVAILABLE
FOR COPYRIGHT \\ IMAGE
UNAVAILABLE
FOR COPYRIGHT \\ IMAGE
UNAVAILABLE
FOR COPYRIGHT REASONS} REASONS

\section{Tern}

Washington. Bernadine Healy, the outgoing director of the US National Institutes of Health (NIH), last week sharply criticized an offer from the Sandoz Pharmaceuticals Corporation of New Jersey to spend $\$ 300$ million over ten years at the Scripps Research Institute in La Jolla, California. In testimony that was not screened by her political bosses, Healy told a congressional subcommittee chaired by US Representative Ron Wyden (Democrat, Oregon) that the proposed contract "does not seem to be in the best interests of the biomedical community, the public or US competitiveness" and that it "does not match similar agreements between other nonprofit laboratories and industry".

The first point is open to interpretation, of course; Wyden is concerned that Sandoz will have a monopoly over $\$ 100$ million a year in federal research in return for its investment, a view hotly disputed by officials from Scripps and Sandoz. An answer to the second point must await the responses of 104 academic institutions to a request

\title{
Terms of Scripps-Sandoz agreement may be more common than its critics believe
}

in a building owned by $\mathrm{OCl} / \mathrm{PMH}$ that will be adjacent to and physically joined by a connecting bridge to a new OCI/PMH facility to be ready the following year. When fully staffed, the institute will employ about 70 people, including a dozen or so senior research scientists.

Mak says that he will be looking for individuals with backgrounds in lymphocyte activation, neurobiology and the regulation of cell growth as well as specialists in immunoregulation, his own area of interest. New employees will also be eligible for cross-appointments in the research divisions of the cancer centre and will be able to apply for research grants from outside sources.

Under the terms of the 10year agreement, the cancer centre will receive $\mathrm{CS} 2$ million from Amgen to fund a fully endowed research chair, most likely in molecular biology, as well as money to expand by 10 positions a year its current level of 60 graduate students and 50 postdoctoral scientists. The cancer centre will also receive payment by Amgen for use of its core facilities, including its animal colonies and media preparation facilities.

Although this will be the first centre of its kind set up by Amgen outside its California headquarters, Billen says that the company has plans to fund two additional research centres - both in the United States.

Diane Gershon made last month by NIH to describe their collaborations with industry. But a preliminary analysis suggests that Healy's description of the agreement as an "aberration" is, in certain respects, incorrect.

At the heart of the Scripps-Sandoz agreement, due to take effect in 1997, is a panel of seven scientists each from Scripps and Sandoz that would decide how to spend $\$ 12$ million of the $\$ 30$ million a year coming from Sandoz. (The rest will go into a general account for nondirected research.) The group, called a Joint Scientific Council, would operate much like an NIH study section, rating proposals submitted by Scripps researchers and funding those it likes best.

That is precisely the way an advisory committee created by the largest existing collaboration between a pharmaceutical company and a US research institution - a \$100-million agreement between Monsanto and Washington University medical school in St Louis, Missouri - has operated since 1982. Once a year, five senior scientists from each institution sift through the re- 